\title{
Improving Efficiency in Power Production and Transmission for Offshore Solar Farms using Bifacial Panel Design and HVDC
}

\author{
BELL DAVID DU HONG, HA THU LE \\ Department of Electrical and Computer Engineering \\ California State Polytechnic University, Pomona \\ Pomona city, California 91768 \\ UNITED STATES OF AMERICA
}

\begin{abstract}
As higher demand for power becomes a global concern and offshore power generation becomes more popular, more options should be explored. This study investigates the use of bifacial photovoltaic (PV) panels for offshore solar farms. In addition, it explores the use of HVDC for transmitting the solar power to onshore grid. The results show that bifacial panels have much higher efficiency compared to monofacial panels where the efficiency improvement ranges from $8.5 \%$ to $24.8 \%$ for a wide range of irradiance $\left(100-1000 \mathrm{~W} / \mathrm{m}^{2}\right)$. The newer Voltage Source Converter (VSC) HVDC has high potential for future deployment thanks to its advantages. However, the harmonics from a considered VSC-HVDC system is severe. Some fitters have been designed to mitigate the harmonics. LC low-pass filters are proved to be most effective where they reduce the Total Harmonics Distortion (THD) of the system output voltage from $68.84 \%$ to $2.93 \%$. The results are supportive for developing offshore solar farms that provide green energy while preserving land for other purposes.
\end{abstract}

Keywords: Bifacial panel, efficiency, HVDC, offshore solar farm, photovoltaic, renewable energy.

Received: January15, 2021. Revised: August 13, 2021. Accepted: August 20, 2021. Published: August 29, 2021.

\section{Introduction}

Climate change is becoming one of the most fundamental issues of the world. Due to harmful effects of global warming, countries are increasingly investing in research of renewable energy sources, especially solar and wind. Solar photovoltaic (PV) and wind energy have been proven to be effective sources which have gained remarkable popularity. Solar energy has become the world fastest growing energy technology in many countries with a gigawatt scale market. The demand for solar PV has been expanding as it is becoming a competitive option for electrical energy generation [1].

Solar energy is received from the sun rays which hit the earth and is commonly known as solar radiation. Solar radiation can be harvested and converted to electricity using photovoltaic technology. Photovoltaic cells produce electricity by absorbing photons and releasing electrons in form of current. The PV cells can be used individually or combined as modules to power from small electrical devices to larger systems [2-4]. Solar PV has a great potential for energy generation since solar energy is clean, widely accessible, and exists in enormous amount [5]. However, there are multiple challenges for developing solar PV. One of the challenges is the availability of land. Purchasing or leasing space for installation of solar panels may be more expensive in the future due to limited available land. The use of land for PV systems may also reduce the space available for growing food and living. This suggests the need to use the available land efficiently for energy, food, and inhabitation [6]. 
A potential solution to the issue of land occupation is to produce energy using solar marine or floating $\mathrm{PV}$ farms. This is an emerging concept that has been solidifying in recent years. Installing solar systems on the ocean is a promising concept that would save money as it does not require the use of land. Additionally, installing PV systems in an offshore location would help with the system cooling because the water typically has a lower temperature than an inland location [7].

Another solution to reduce the space required for solar systems is to increase their power production efficiency. When the first PV cells were developed, the efficiency was ranging from 5\%-6\%. Currently, with the PV technological improvement, this number has increased to approximately $22 \%$ [8]. The solar energy industry could grow more rapidly by developing cost-effective offshore solar power systems [9]. The open space on the ocean lowers the shading on the PV panels which likely increase their power production efficiency.

A typical conventional solar panel is monofacial (one-sided), where it has only one interface to absorb the sun light and converts it into electricity. It collects light from the front side, as the opaque back sheet prevents collection of light from the ground or surrounding environment. The lost energy from albedo (solar radiation reflected from the earth surface) can be partially recovered by finding a way to utilize the back of the panel. Bifacial solar panels utilize both sides of each panel and cells that are optically transparent. The concept of bifacial panels has been experimented and analyzed since the 1980's. Studies have shown that an isolated bifacial panel can have a $50 \%$ extra output compared to a monofacial panel. Moreover, bifacial panels have a lower operating temperature and better temperature coefficient which increase their lifetime [10]. Despite these advantages, bifacial panel performance models are not well established compared to monofacial panels and field validation data is scarce [11]. Recognizing the gap, this study investigates the performance of bifacial panels in terms of efficiency. The findings are expected to help developing bifacial solar systems for offshore installation.

Another issue regarding offshore solar farms that needs attention is power transmission issue. It is relevant as offshore solar farms are likely located far from shore where the power is demanded.
Transmission losses likely increase with the increase in transmission distances. Therefore, exploring viable options for integrating offshore power sources into the onshore grid is crucial. High voltage AC (HVAC) transmission lines have been used for offshore wind farms. HVAC is not the most practical method because capacitance of the undersea cables is much higher than overhead cables, resulting in possible greater power losses. Recently, voltage source converter based high voltage DC (VSCHVDC) technology has been considered because of its advantages [12-14].

Based on the above analysis, this study investigates two methods to improve the power production of offshore solar farms, as follows:

1) Improvement of PV system efficiency through utilization of bifacial panels.

2) Improvement of solar power transmission effectiveness using HVDC lines.

The first method focuses on modeling bifacial panels, quantifying their efficiency and comparing their efficiency with that of monofacial panels. The second approach focuses on studying the transmission effectiveness of HVDC lines in terms of power loss, voltage drop, and harmonic condition.

\section{Study of bifacial PV panels: modeling, efficiency, and comparison with monofacial PV panels}

\subsection{Basic concepts of monofacial panel and modeling}

A PV cell consists of two layers of semiconducting material. One layer has a surplus number of electrons while the other layer has the depleted number of electrons. When the cell is exposed to sunlight, photons will be absorbed causing electrons to reach excitement state which will result in current flow in a closed circuit. The main parameters that determine the performance of a PV cell include maximum power, open circuit voltage, short circuit current, maximum power point voltage, maximum power point current, and efficiency. The key factors that affect the PV cell efficiency are solar irradiance and cell temperature $[15,16]$. 


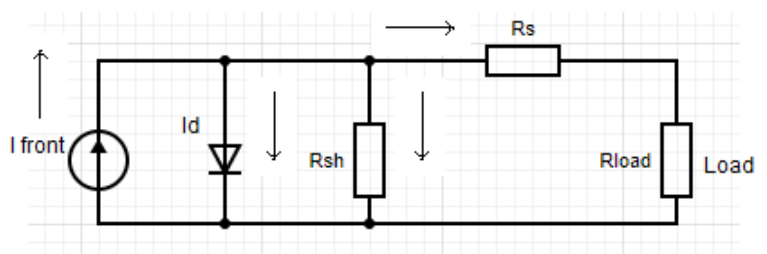

Fig. 1 Monofacial module equivalent circuit [11]

The equivalent circuit of a monofacial module is shown in Fig. 1. From the equivalent circuit we can assume that equation (1) represents the summation of currents with their proper polarity[11].

$$
I=I_{p h-f}-I_{d}-I_{s h}
$$

Equation (1) will be utilized when modeling the PV cell. An increase in the series resistance or a decrease in the shunt resistance will result in a reduction of the output voltage. A solar cell may operate over a wide range of voltages and currents. [17]. For modeling of the monofacial solar panel, we also use the following equations [18] :

$$
\begin{aligned}
& I_{p h-f}=\left[I_{s c}+k_{i} *(T-298) * \frac{G}{1000}\right] \\
& \left.I_{0}=I_{r s} *\left(\frac{T}{T_{n}}\right)^{3} e^{\left[q * E_{g 0} * \frac{1}{T^{2}}-\frac{1}{T}\right.}\right] \\
& I_{r S}=\frac{I_{S c}}{e^{\frac{q * V O C}{n * N_{S} * K * T}}-1} \\
& I_{s h}=\frac{V+I * R_{S}}{R_{S h}} \\
& I=I_{p h-f}-I_{0}\left[e^{q * \frac{V+I * R_{S}}{n_{*} N_{N} * T}-1}\right]-I_{s h}
\end{aligned}
$$

Equation (2) represents the photocurrent of the front side of the panel, which is also shown in (1). Equation (3) represents the saturation current that will be needed to calculate the diode current shown in (6). Equation (4) is the reverse saturation current, (5) represents the current through the shunt load and (6) is the same representation of (1) with the diode current expanded.

\subsection{Basic concepts of bifacial panel and modeling}

Bifacial solar panels were proposed in 1960 that uses a P-N junction on each surface of a silicon wafer. The main goal was to increase the energy conversion efficiency of the silicon cell. The installation of the world first large-scale bifacial PV power plant took place in Hokuto (Japan) in 2013, with a total capacity of 1.25 MW. This plant has reported a bifacial gain of $19.5 \%$, producing more than $1.2 \mathrm{MWh} / \mathrm{kW} /$ year [19]. Bifacial panels have been in the market for a long time with a slow growth. However, its market share is expected to rise. The reason is, in monofacial PV cell standard technology, the back-surface field (BSF) represents a large percentage of energy collected but is not as efficient as bifacial technology. The main difference between a conventional monofacial cell and a bifacial cell is that the latter rear surface must have metal contacts instead of being fully blocked with a metal sheet. Subsequently, more solar energy or radiation can be obtained from the latter front and rear surfaces.

A key parameter to define the efficiency of a bifacial panel lays on its bifaciality. The bifacial gain can be defined by (7) as the ratio between the rear side efficiency and the front side efficiency of the panel. The bifacial gain can also be determined as the ratio of the power output between each side under standard test conditions [17].

$$
\text { Bifacial gain }=\frac{\eta_{\text {rear }}}{\eta_{\text {front }}}=\frac{P_{S T C, \text { rear }}}{P_{S T C, \text { front }}}
$$

There are three common types of construction for the bifacial panel as the properties and materials are different. Currently, there is Heterojunction with Intrinsic Thin Layer (HIT), Passivated Emitter and Rear Cell (PERC), and Passivated emitter, Rear totally diffused (PERT) solar cells. Each one tends to have a different bifaciality level. PERT and HIT have a higher bifacial gain of around $90 \%$ as compared with around $70 \%$ for PERC [20].

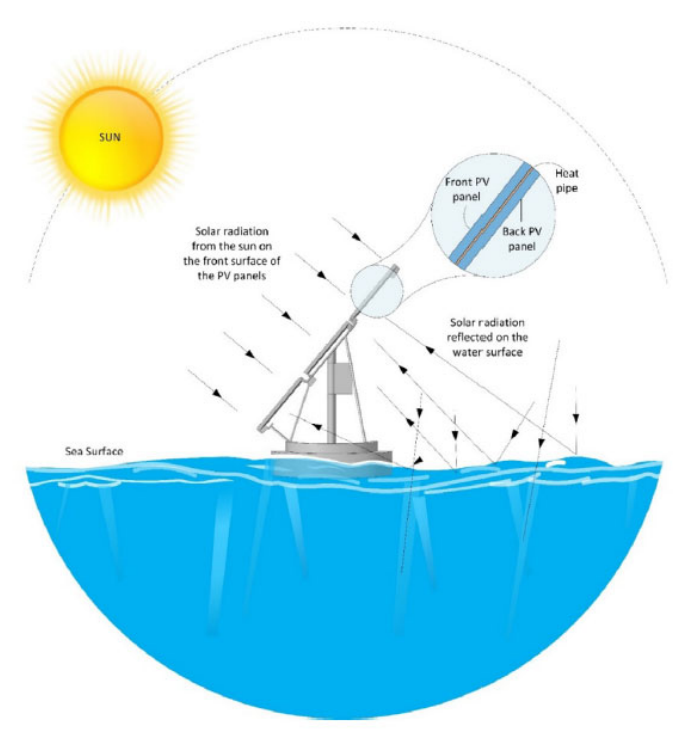

Fig. 2 Bifacial PV panel behavior on water [6] 
Figure 2 represents the behavior of a bifacial panel installed on water. Since the bifacial panel is expected to use the reflected radiation, it is more sensitive to its surroundings.

The electrical modeling of a bifacial panel is based on the solar irradiance model, which shows how solar radiation travels in Fig. 2. It follows that another key factor that needs to be addressed is the albedo. The albedo can be defined as the property of the surface to reflect energy. Albedo is a way to measure diffused reflection of solar radiation out of the total radiation emanated. It typically ranges between zero and one where zero being the lowest or no reflection and one being the highest or total reflection of solar radiation. It is known that black bodies tend to have a lower albedo while lighter colors tend to have a higher albedo. Figure 2 shows how solar radiation would impact the performance of a bifacial panel if the water surface were assumed to have a lower or higher albedo.

Figure 3 is an example of how and why the albedo would be a key factor in determining the efficiency of bifacial photovoltaic panels as less irradiance is reflected if the surface is of low albedo.

Albedo estimation tends to use a fixed albedo when it comes to measuring the reflection on bifacial panels. The albedo on the sea during hours where the sun is at its highest is estimated to be around 0.05 while during low sun hours the albedo is assumed to be 0.4 [21]. Moreover, due to weather conditions, the reflectance from the sea could be less than expected due to cloudiness on the sky. For simplicity, we assume that these external factors are constant. The albedo used in our bifacial system is 0.22 .

From Fig. 4, the elevation of the panel, meaning how high from the surface the panel is installed, influences the energy collected. If the panel is too close to the surface, this would produce self-shading which, in turns, reduces the solar radiation reflected to the rear panel. Moreover, the tilt angle would also provoke effects on the bifacial panel output power. All the factors concerning the surrounding of the panel have an immense influence on the energy yield of a bifacial panel [9] [22].

Studies were conducted to evaluate the effect of the incident power received from the sun and the power ratio effectiveness of a bifacial panel when facing north and south, compared to when facing east and west for a whole day [22].
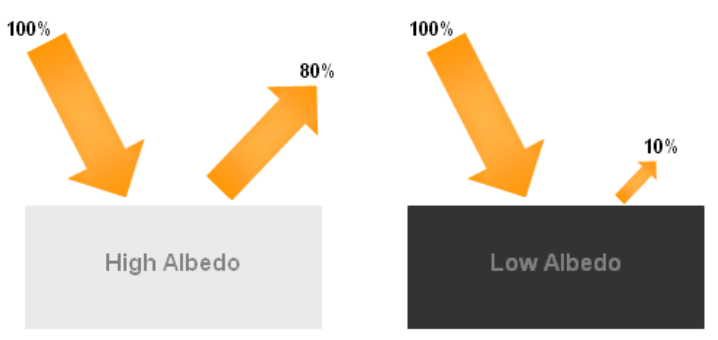

Fig. 3 Albedo representation [23]

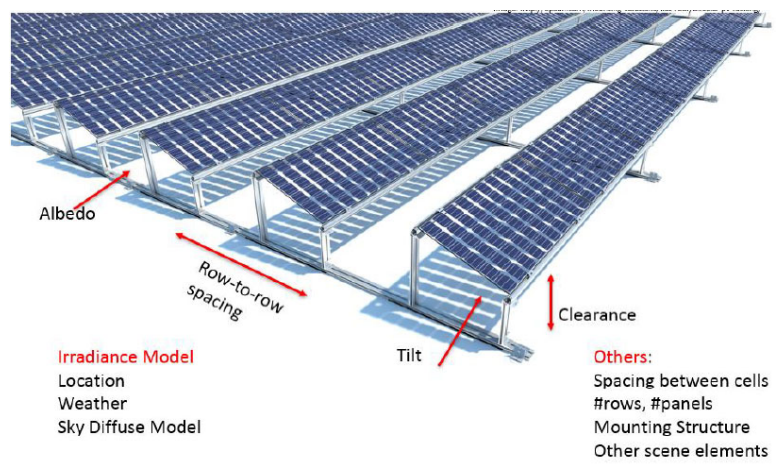

Fig. 4 Albedo, title angle, rear irradiance [9]

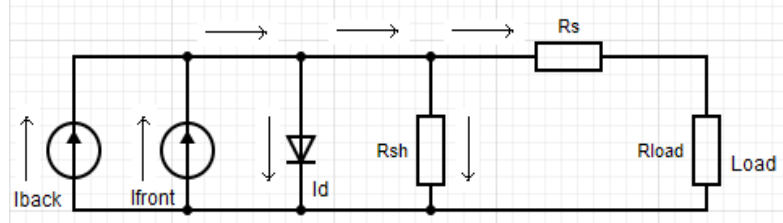

Fig. 5 Bifacial module equivalent circuit

From the study results, the north and south facing module perform better than the east and west facing module. This is mainly because the east and west facing modules were getting insignificant irradiance when the sun is at 90 degrees from them, resulting in a higher incident power ratio [22].

When the ground albedo increases, the optimum tilt angle for monofacial modules tend to be higher than the one for bifacial modules because the albedo also alters or influences the front side of the PV module. For this study, we have the tilt angle set to $30^{\circ}$ since this seems to be an ideal angle for a panel located in the West Coast of the United States. Typically, this value would range between $25^{\circ}$ to $40^{\circ}$ based on the time of the year [24].

For a bifacial module, the cells that are closer to the surface receive less radiation since the viewfactor with respect to the diffuse sky and to the non- 
shaded surface is lower. This same concept applies if the module is close to the reflective surface and is more conspicuous as the albedo is higher. Nonetheless, increasing the module height would increase the installation cost. Higher elevation may also complicate the module maintenance [3].

Figure 4 depicts the parameters impacting the efficiency of a bifacial panel, which include the following: (i) Row to row distance or spacing, (ii) Clearance from the ground, (iii) Module tilt, (iv) Albedo, and (v) Shading.

For modeling of our bifacial panel, we use the equivalent circuit in Fig. 5, which represents the characteristics and main variables of the panel. It is called 2-junction model. Since the properties of the bifacial panel are the same for the monofacial panel, we have the diode current, the shunt resistor current, and the front photocurrent. In addition to these, we implement the integration of the photocurrent from the backside of the panel. Additionally, we consider the irradiance ratio which would be close to our albedo value [5].

$$
\text { Irradiance Ratio }(X)=G_{\text {rear }} / G_{\text {front }}
$$

Where $\mathrm{G}$ means the incident radiance of each side respectively.

$$
P_{\text {bidacial }}=I_{s c, b i} V_{o c, b i} F F_{b i}
$$

We apply the short circuit current of the bifacial panel, the open circuit voltage, and the fill factor as represented in (10) through (13) to measure the efficiency of the proposed model since this method has shown accurate results when measuring power outputs within $1 \%$ of the measured results [5].

$$
\begin{gathered}
I_{s c, b i}=R_{s c} I_{s c, \text { front }}=\left(1+x \frac{I_{s c, \text { rear }}}{I_{s c, \text { front }}}\right) I_{s c, \text { front }} \\
V_{o c, b i}=V_{o c, \text { front }}+\frac{\left(V_{o c, \text { rear }}-V_{o c, \text { front }}\right) \ln \left(R_{i s c}\right)}{\ln \left(I_{s c, \text { rear }}-I_{s c, \text { front }}\right)} \\
F F_{b i}=p F F-R_{\text {isc }} \frac{V_{o c, \text { front }}}{V_{o c . b i}}\left(p F F-F F_{\text {front }}\right) \\
p F F=\frac{\left(\frac{I_{s c, \text { rear }}}{I_{s c, \text { front }}}\right) F_{\text {front }}-\frac{V_{o c, \text { rear }}}{V_{o c, \text { front }}} F F_{\text {rear }}}{\left(\frac{I_{s c, \text { rear }}}{I_{s c, \text { front }}}\right)-\frac{V_{o c, \text { rear }}}{V_{o c, \text { front }}}}
\end{gathered}
$$

\subsection{Verification of monofacial panel model}

The accuracy of the monofacial model built based on the concepts in Section 2.1 for our study is verified by comparing it with a MATLAB solar PV model. The results are shown in tables 1, 2, and 3. The PV model is rated at $215 \mathrm{~W}$. Figure 6 shows our model (top) and the MATLAB model (bottom, blue color)

\begin{tabular}{|c|c|c|c|c|c|c|}
\hline & \multicolumn{2}{|c|}{$\begin{array}{c}\text { Solar Model } \\
\text { Created }\end{array}$} & \multicolumn{2}{|c|}{$\begin{array}{c}\text { MATLAB Solar } \\
\text { Model }\end{array}$} & \multicolumn{2}{|c|}{$\begin{array}{c}\text { Percent } \\
\text { difference }\end{array}$} \\
\hline $\begin{array}{l}\text { Irradiance } \\
\text { (W/m2) }\end{array}$ & $\begin{array}{l}V \text { at } \\
10 C^{\circ}(V)\end{array}$ & $\begin{array}{l}\text { I at } \\
10 \mathrm{C}^{\circ}(\mathrm{A})\end{array}$ & $\begin{array}{l}V \text { at } \\
10 C^{\circ}(V)\end{array}$ & $\begin{array}{l}\text { I at } \\
10 \mathrm{C}^{\circ}(\mathrm{A})\end{array}$ & $\begin{array}{l}\% V \\
10 C^{\circ}\end{array}$ & $\begin{array}{l}\% \mathrm{l} \\
10 \mathrm{C}^{\circ}\end{array}$ \\
\hline 100 & 3.83 & 0.77 & 3.87 & 0.77 & 0.93 & 0.93 \\
\hline 200 & 7.66 & 1.53 & 7.72 & 1.54 & 0.75 & 0.78 \\
\hline 300 & 11.49 & 2.30 & 11.56 & 2.31 & 0.61 & 0.61 \\
\hline 400 & 15.32 & 3.06 & 15.38 & 3.08 & 0.39 & 0.42 \\
\hline 500 & 19.15 & 3.83 & 19.20 & 3.84 & 0.26 & 0.23 \\
\hline 600 & 22.97 & 4.59 & 22.99 & 4.60 & 0.09 & 0.11 \\
\hline 700 & 26.64 & 5.33 & 26.73 & 5.35 & 0.34 & 0.34 \\
\hline 800 & 29.34 & 5.87 & 29.96 & 5.99 & 2.07 & 2.05 \\
\hline 900 & 30.74 & 6.15 & 31.84 & 6.37 & 3.45 & 3.45 \\
\hline 1000 & 31.52 & 6.31 & 32.84 & 6.57 & 4.02 & 3.96 \\
\hline
\end{tabular}
and the parameter measurement using Simulink Simscape toolbox.

\begin{tabular}{|c|c|c|c|c|c|c|}
\hline \multirow[b]{2}{*}{$\begin{array}{l}\text { Irradiance } \\
\text { (W/m2) }\end{array}$} & \multicolumn{2}{|c|}{$\begin{array}{c}\text { Solar Model } \\
\text { Created }\end{array}$} & \multicolumn{2}{|c|}{$\begin{array}{c}\text { MATLAB Solar } \\
\text { Model }\end{array}$} & \multicolumn{2}{|c|}{$\begin{array}{c}\text { Percent } \\
\text { difference }\end{array}$} \\
\hline & $\begin{array}{l}V \text { at } \\
25 C^{\circ}(V)\end{array}$ & $\begin{array}{l}\text { I at } \\
25 \mathrm{C}^{\circ}(\mathrm{A})\end{array}$ & $\begin{array}{l}V \text { at } \\
25 C^{\circ}(V)\end{array}$ & $\begin{array}{l}\text { I at } \\
25 \mathrm{C}^{\circ}(\mathrm{A})\end{array}$ & $\begin{array}{l}\% V \\
25 C^{0}\end{array}$ & $\begin{array}{l}\% 1 \text { at } \\
25 \mathrm{C}^{0}\end{array}$ \\
\hline 100 & 3.85 & 0.77 & 3.93 & 0.79 & 1.83 & 1.83 \\
\hline 200 & 7.71 & 1.54 & 7.84 & 1.57 & 1.67 & 1.72 \\
\hline 300 & 11.56 & 2.31 & 11.74 & 2.35 & 1.53 & 1.49 \\
\hline 400 & 15.41 & 3.08 & 15.62 & 3.12 & 1.34 & 1.31 \\
\hline 500 & 19.27 & 3.85 & 19.49 & 3.90 & 1.13 & 1.18 \\
\hline 600 & 23.10 & 4.62 & 23.33 & 4.66 & 0.99 & 0.86 \\
\hline 700 & 26.70 & 5.34 & 26.89 & 5.38 & 0.71 & 0.69 \\
\hline 800 & 29.21 & 5.84 & 29.31 & 5.86 & 0.34 & 0.34 \\
\hline 900 & 30.53 & 6.11 & 30.57 & 6.11 & 0.13 & 0.13 \\
\hline 1000 & 31.30 & 6.26 & 31.32 & 6.27 & 0.06 & 0.06 \\
\hline
\end{tabular}

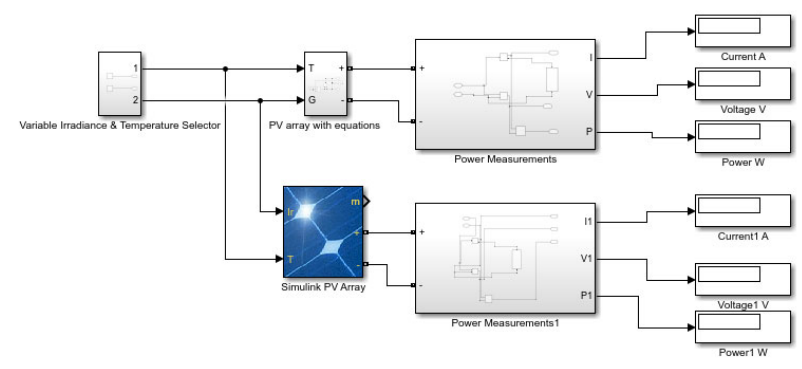

Fig. 6 Verification of the study monofacial model

Table 1 Comparison of V-I parameters at $10^{\circ} \mathrm{C}$

Table 2 Comparison of V-I parameters at $25^{\circ} \mathrm{C}$ 
Table 3 Comparison of V-I parameters at $40^{\circ} \mathrm{C}$

\begin{tabular}{|c|c|c|c|c|c|c|}
\hline & \multicolumn{2}{|c|}{$\begin{array}{l}\text { Solar Model } \\
\text { Created }\end{array}$} & \multicolumn{2}{|c|}{$\begin{array}{l}\text { MATLAB Solar } \\
\text { Model }\end{array}$} & \multicolumn{2}{|c|}{$\begin{array}{c}\text { Percent } \\
\text { difference }\end{array}$} \\
\hline $\begin{array}{l}\text { Irradiance } \\
\text { (W/m2) }\end{array}$ & $\begin{array}{l}V \text { at } \\
40 C^{\circ}(V)\end{array}$ & $\begin{array}{l}\text { I at } \\
40 \mathrm{C}^{\circ}(\mathrm{A})\end{array}$ & $\begin{array}{l}V \text { at } \\
40 C^{\circ}(V)\end{array}$ & $\begin{array}{l}\text { I at } \\
40 C^{\circ}(A)\end{array}$ & $\begin{array}{l}\% \mathrm{~V} \\
\text { at } \\
40 \mathrm{C}^{\circ}\end{array}$ & $\begin{array}{l}\% l \\
\text { at } \\
40 C^{\circ}\end{array}$ \\
\hline 100 & 3.88 & 0.78 & 3.99 & 0.80 & 2.73 & 2.71 \\
\hline 200 & 7.76 & 1.55 & 7.96 & 1.59 & 2.54 & 2.51 \\
\hline 300 & 11.63 & 2.33 & 11.92 & 2.38 & 2.43 & 2.39 \\
\hline 400 & 15.51 & 3.10 & 15.86 & 3.17 & 2.21 & 2.21 \\
\hline 500 & 19.38 & 3.88 & 19.78 & 3.96 & 2.02 & 2.00 \\
\hline 600 & 23.23 & 4.65 & 23.57 & 4.71 & 1.44 & 1.44 \\
\hline 700 & 26.73 & 5.35 & 26.54 & 5.31 & 0.72 & 0.73 \\
\hline 800 & 29.05 & 5.81 & 28.20 & 5.84 & 3.01 & 0.51 \\
\hline 900 & 30.30 & 6.06 & 29.14 & 5.83 & 3.98 & 4.00 \\
\hline 1000 & 31.06 & 6.21 & 29.76 & 5.95 & 4.37 & 4.39 \\
\hline
\end{tabular}

Note: For tables 1, 2, and 3, V is the model output voltage and I is the output current.

Tables 1, 2, and 3 shows that our model V-I outputs are close to that of the MATLAB model. For a wide range of solar irradiance $\left(100-1000 \mathrm{~W} / \mathrm{m}^{2}\right)$, the difference never exceeds $5 \%$. Under standard test temperature of $25^{\circ} \mathrm{C}$, the difference is less than $2 \%$.

The reason why there is a higher difference in V-I parameters at $10^{\circ} \mathrm{C}$ and $40^{\circ} \mathrm{C}$ is that the MATLAB model sets its variables as percentage of the temperature while the model that we built does not. Under standard test conditions $\left(1000 \mathrm{~W} / \mathrm{m}^{2}\right.$ irradiance and temperature of $25^{\circ} \mathrm{C}$, Table 2) the V-I outputs of our model are essentially the same as the MATLAB model where the difference is $0.06 \%$. This suggests that our model is sufficiently accurate for representing the monofacial panel.

\subsection{Modeling of bifacial panel: Comparison between 2-junction and 2-monofacial models}

The model of the bifacial panel for our study is built based on the concepts in Section 2.2 and the equivalent circuit of Fig. 5. It is called 2 -junction model. To deepen understanding of the bifacial panel modeling, we consider another model. This model treats a bifacial panel as two individual monofacial panels. It is called 2-monofacial model where the equivalent circuit is shown in Fig. 7. Each of the monofacial panels could have either a single diode or two diodes. To be consistent with our initial model of the monofacial panel, we treat this as a single diode panel. We use two bifacial PV panels available in the market (Table 4) to analyze the two models of the bifacial panel (i.e. the 2-junction and 2-monofacial models).

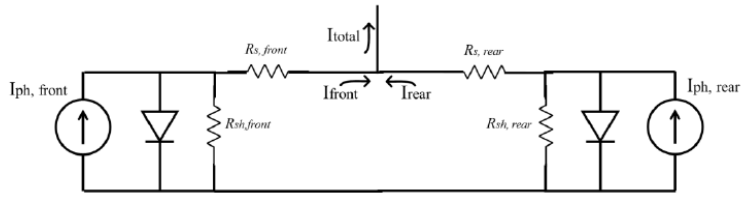

Fig. 7 Equivalent circuit with two monofacial panels combined to represent a bifacial panel

Table 4 Commercial bifacial system characteristics

\begin{tabular}{|l|r|r|}
\hline Model & LR6-72BP & LG390N2T-J5 \\
\hline Maximum Power (Pmax) & $355 \mathrm{~W}$ & $390 \mathrm{~W}$ \\
\hline $\begin{array}{l}\text { Voltage at Maximum } \\
\text { Power (Vmpp) }\end{array}$ & $39.2 \mathrm{~V}$ & $40.7 \mathrm{~V}$ \\
\hline $\begin{array}{l}\text { Current at Maximum } \\
\text { Power (Impp) }\end{array}$ & $9.06 \mathrm{~A}$ & $9.59 \mathrm{~A}$ \\
\hline Open Circuit Voltage (Voc) & $48.1 \mathrm{~V}$ & $49.5 \mathrm{~V}$ \\
\hline Short Circuit Current (Isc) & $9.61 \mathrm{~A}$ & $10.14 \mathrm{~A}$ \\
\hline Panel Efficiency & $18 \%$ & $18.8 \%$ \\
\hline $\begin{array}{l}\text { Power Tolerance } \\
\text { (Positive) }\end{array}$ & $1.5 \%$ & $3 \%$ \\
\hline
\end{tabular}

From Table 4, the first commercial system is LR672BP and the second system is LG 390N2T-J5. Both systems have 72 cells. These systems are used in the two models (2-junction and 2-monofacial), which are simulated using Simulink Simscape toolbox. The irradiance input varies from $100 \mathrm{~W} / \mathrm{m}^{2}$ to $1000 \mathrm{~W} / \mathrm{m}^{2}$ and the temperature is $25^{\circ} \mathrm{C}$. The results are presented in Table 5 and Table 6 . Note that the two commercial systems have slightly different power ratings $(355 \mathrm{~W}$ and $390 \mathrm{~W}$ ) which likely lead to slight differences in their voltage, current and power outputs.

The main difference between these two models can be seen by comparing the outputs in Table 5 and Table 6, as well as comparing Fig. 5 with Fig. 7. The main noticeable difference between them is the inclusion of an additional current in the 2-monofacial model (Fig. 7) as there are two diodes. Meanwhile, in the 2-junction model (Fig. 5) there is only one diode. There are two shunt currents in the 2-monofacial model (Fig. 7) while there is only one shunt current in the 2-junction model (Fig. 5). These factors likely lead the difference in the measured results of Table 5 and Table 6.

However, the overall measured data show that the two models (2-junction and 2-monofacial) have very similar characteristics (in terms of voltage, current and power outputs). From Table 5, the difference in the power output between the two models ranges from $1.69 \%$ to $1.84 \%$. 
Table 5 Bifacial model comparison LG 390N2T-J5

\begin{tabular}{|c|c|c|c|c|c|c|c|}
\hline \multirow[b]{2}{*}{$\begin{array}{l}\text { Irradi- } \\
\text { ance, } \\
\text { W/m2 }\end{array}$} & \multicolumn{3}{|c|}{ 2-Monofacial Model } & \multicolumn{3}{|c|}{ 2-Junction Model } & \multirow{2}{*}{$\begin{array}{c}\text { Power } \\
\text { Diff, \% } \\
\% \\
\end{array}$} \\
\hline & $\begin{array}{l}\text { I } \\
\text { (A) }\end{array}$ & $\begin{array}{l}\text { V } \\
\text { (V) }\end{array}$ & $\begin{array}{l}P \\
\text { (W) }\end{array}$ & $\begin{array}{l}\text { I } \\
\text { (A) }\end{array}$ & $\begin{array}{l}V \\
\text { (V) }\end{array}$ & $\begin{array}{c}P \\
\text { (W) }\end{array}$ & \\
\hline 1000 & 12.12 & 33.94 & 411.35 & 12.24 & 33.04 & 404.41 & 1.69 \\
\hline 900 & 10.92 & 30.58 & 333.93 & 11.02 & 29.76 & 327.96 & 1.79 \\
\hline 800 & 9.711 & 27.19 & 264.04 & 9.80 & 26.46 & 259.31 & 1.79 \\
\hline 700 & 8.497 & 23.79 & 202.14 & 8.58 & 23.15 & 198.51 & 1.80 \\
\hline 600 & 7.283 & 20.39 & 148.50 & 7.35 & 19.84 & 145.82 & 1.80 \\
\hline 500 & 6.069 & 16.99 & 103.11 & 6.13 & 16.54 & 101.31 & 1.75 \\
\hline 400 & 4.855 & 13.6 & 66.03 & 4.90 & 13.23 & 64.83 & 1.82 \\
\hline 300 & 3.642 & 10.2 & 37.15 & 3.68 & 9.92 & 36.46 & 1.84 \\
\hline 200 & 2.428 & 6.798 & 16.51 & 2.45 & 6.62 & 16.21 & 1.81 \\
\hline 100 & 1.214 & 3.399 & 4.13 & 1.23 & 3.31 & 4.05 & 1.83 \\
\hline
\end{tabular}

Table 6 Bifacial model comparison LR6 72BP

\begin{tabular}{|c|c|c|c|c|c|c|c|}
\hline \multirow[b]{2}{*}{$\begin{array}{l}\text { Irradi- } \\
\text { ance, } \\
\text { //m2 }\end{array}$} & \multicolumn{3}{|c|}{ 2-Monofacial Model } & \multicolumn{3}{|c|}{ 2-Junction Model } & \multirow{2}{*}{$\begin{array}{c}\begin{array}{c}\text { Power } \\
\text { Diff., \% }\end{array} \\
\%\end{array}$} \\
\hline & $\begin{array}{c}1 \\
\text { (A) }\end{array}$ & $\begin{array}{l}V \\
\text { (V) }\end{array}$ & $\begin{array}{c}P \\
\text { (W) }\end{array}$ & $\begin{array}{c}1 \\
\text { (A) }\end{array}$ & $\begin{array}{l}\mathbf{v} \\
\text { (V) }\end{array}$ & $\begin{array}{c}P \\
\text { (W) }\end{array}$ & \\
\hline 1000 & 10.99 & 30.78 & 368.72 & 11.6 & 31.32 & 363.31 & 1.49 \\
\hline 900 & 9.90 & 27.71 & 299.02 & 10.45 & 28.21 & 294.79 & 1.43 \\
\hline 800 & 8.80 & 24.63 & 236.25 & 9.29 & 25.1 & 233.18 & 1.32 \\
\hline 700 & 7.70 & 21.55 & 180.82 & 8.127 & 21.94 & 178.31 & 1.41 \\
\hline 600 & 6.60 & 18.47 & 132.83 & 6.966 & 18.81 & 131.03 & 1.38 \\
\hline 500 & 5.50 & 15.40 & 92.29 & 5.805 & 15.67 & 90.96 & 1.46 \\
\hline 400 & 4.40 & 12.32 & 59.07 & 4.644 & 12.54 & 58.24 & 1.44 \\
\hline 300 & 3.30 & 9.24 & 33.22 & 3.483 & 9.404 & 32.75 & 1.41 \\
\hline 200 & 2.20 & 6.16 & 14.76 & 2.322 & 6.269 & 14.56 & 1.40 \\
\hline 100 & 1.10 & 3.08 & 3.69 & 1.161 & 3.135 & 3.64 & 1.43 \\
\hline
\end{tabular}

Table 7 Monofacial vs. bifacial panel comparison

\begin{tabular}{|r|r|r|r|r|}
\cline { 2 - 5 } \multicolumn{1}{c|}{} & \multicolumn{1}{c|}{$\begin{array}{c}\text { Monofacial } \\
\text { panel }\end{array}$} & \multicolumn{2}{c|}{$\begin{array}{c}\text { Bifacial } \\
\text { panel }\end{array}$} & \multicolumn{1}{c|}{ Results } \\
\hline $\begin{array}{r}\text { Irradiance, } \\
\text { W/m2 }\end{array}$ & $\begin{array}{c}\text { Power at } \\
\mathbf{2 5 C}^{\circ} \text { (W) }\end{array}$ & $\begin{array}{c}\text { Power at } \\
\mathbf{2 5 C}^{\circ} \text { (W) }\end{array}$ & $\begin{array}{c}\text { Adjusted } \\
\text { Power }\end{array}$ & $\begin{array}{c}\text { \% } \\
\text { Improved }\end{array}$ \\
\hline $\mathbf{1 0 0 0}$ & 195.97 & 404.30 & 222.88 & 8.54 \\
\hline $\mathbf{9 0 0}$ & 186.39 & 328.10 & 180.88 & 10.86 \\
\hline $\mathbf{8 0 0}$ & 170.62 & 259.30 & 142.95 & 16.22 \\
\hline $\mathbf{7 0 0}$ & 142.60 & 198.51 & 109.44 & $\mathbf{2 3 . 2 6}$ \\
\hline $\mathbf{6 0 0}$ & 106.72 & 145.82 & 80.39 & $\mathbf{2 4 . 6 7}$ \\
\hline $\mathbf{5 0 0}$ & 74.25 & 101.31 & 55.85 & 24.78 \\
\hline $\mathbf{4 0 0}$ & 47.51 & 64.83 & 35.74 & 24.78 \\
\hline $\mathbf{3 0 0}$ & 26.73 & 36.46 & 20.10 & 24.79 \\
\hline $\mathbf{2 0 0}$ & 11.88 & 16.21 & 8.93 & 24.77 \\
\hline $\mathbf{1 0 0}$ & 2.97 & 4.05 & 2.23 & 24.81 \\
\hline
\end{tabular}

From Table 6, the difference in the power output ranges from $1.32 \%$ to $1.49 \%$. Under standard test conditions (irradiance of $1000 \mathrm{~W} / \mathrm{m}^{2}$ and temperature of $25^{\circ} \mathrm{C}$ ) the power outputs of 2-monofacial and 2junction models are $411.4 \mathrm{~W}$ and $404.4 \mathrm{~W}$ respectively (Table 5) for LG 390N2T-J5 commercial system. These numbers are close to the manufacturer rating of $390 \mathrm{~W}$. The 2-junction model output is closer to the manufacturer rating where its output is higher than the rating by $3.7 \%$. The manufacturer specifies the system power tolerance of $+3 \%$ (Table 4). For LR6 72BP, the 2-monofacial and the 2 -junction models output $368.7 \mathrm{~W}$ and $363.3 \mathrm{~W}$ in the stated order (Table 6). These numbers are also close to the manufacturer rating of $355 \mathrm{~W}$. Again, the 2-junction model power output is closer to the manufacturer rating where its output is higher than the rating by $2.3 \%$. The manufacturer specifies the power tolerance of $+1.5 \%$ for this system (Table 4 ).

The results suggest that both the 2-monofacial and the 2-junction models are relatively accurate. Our 2-junction model has higher accuracy and is used to represent the bifacial panel in the following comparison analysis with the monofacial panel.

\subsection{Comparison of power production efficiency of monofacial and bifacial panels}

To compare the efficiency between the bifacial and monofacial panels, commercial system 1SOLTECJ-215-WH (rated 215W) is implemented for the monofacial panel and commercial system LG 390N2T-J5 (rated 390W) is used for the bifacial panel. The monofacial panel is represented using the model described in Section 2.1 and the bifacial panel is represented using the 2-junction model (Section 2.2). The simulation results are obtained by Simulink Simscape and shown in Table 7. Since the power rating of LG 390N2T-J5 is higher than 1SOLTECJ$215-\mathrm{WH}$, the former power output is adjusted to be equivalent to the latter for comparison.

The results from Table 7 show that the bifacial panel is significantly more efficient compared to the monofacial panel. For a wide range of irradiance $\left(100-1000 \mathrm{~W} / \mathrm{m}^{2}\right)$, the bifacial panel consistently produces more power than the monofacial panel by $8.54 \%$ to $24.81 \%$. Another highlight result is that the bifacial panel outputs over $24 \%$ more power for lower irradiance levels, namely $100-600 \mathrm{~W} / \mathrm{m}^{2}$.

In the West Coast of the United States, the average irradiance ranges between $600 \mathrm{~W} / \mathrm{m}^{2}$ and $700 \mathrm{~W} / \mathrm{m}^{2}$. Under these irradiance levels, the bifacial panel produces over $23 \%$ more power than the monofacial panel. All the results point to a promising future of the bifacial panels where they can be used for solar farms on the oceans, such as the U.S. Western and Eastern seas and other seas in the world. 


\section{Improving solar power transmission effectiveness using HVDC lines}

\subsection{Overview of HVDC technology and scheme for connecting offshore farms}

Some basic goals of a power transmission system are to lower power losses and the system cost. The use of HVDC technology could help achieve these goals. An HVDC line only requires two conductors while an AC 3-phase line requires three conductors. Less conductors mean less power loss. In addition, the saving from having less conductors and their insulators may reduce the cost of the system. Furthermore, the HVDC lines suffer less from corona loss compared to AC lines. As the HVDC system lacks frequency, losses like the skin effect and proximity effect do not occur there [25].

HVDC is a versatile and flexible technology, making it an ideal solution for integrating renewable energy, both offshore and onshore. Recently, voltage-source-converter-based high-voltage DC (VSC-HVDC) transmission technologies have been considered due to their grid-forming capabilities. Voltage Source Converter (VSC) is a newer technology based on transistors with a reduced footprint compared to line commutated converter (LCC) technology. VSC is a promising technology for submarine or land cables. There are a few differences between these two as LCC-HVDC systems have been more common in the previous decade but could be replaced by VSC-HVDC due to its increasing popularity.

Table 8 LCC HVDC vs. VSC HVDC [26]

\begin{tabular}{|c|c|c|}
\hline Technology & LCC-HVDC & VSC-HVDC \\
\hline Semiconductor & Thyristor & IGBT \\
\hline Power Control & Active & Active/Reactive \\
\hline AC Filters & Yes & No \\
\hline $\begin{array}{c}\text { Black Start } \\
\text { Capability }\end{array}$ & $\begin{array}{c}\text { No (Need additional } \\
\text { equipment) }\end{array}$ & Yes \\
\hline $\begin{array}{c}\text { Level of } \\
\text { Harmonics }\end{array}$ & High & Low \\
\hline Site Area & $\begin{array}{c}\text { Large site due to } \\
\text { harmonic filters }\end{array}$ & $\begin{array}{c}\text { Compact site } \\
\text { area }\end{array}$ \\
\hline Bidirectional & $\begin{array}{c}\text { Current direction } \\
\text { does not change }\end{array}$ & $\begin{array}{c}\text { Current direction } \\
\text { changes to } \\
\text { change power } \\
\text { direction }\end{array}$ \\
\hline Multiterminal & No & Yes \\
\hline
\end{tabular}

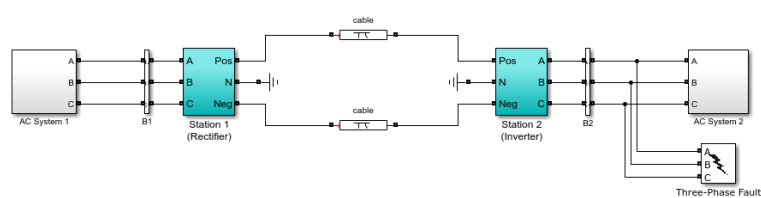

Fig. 9 Typical VSC-HVDC model [26]

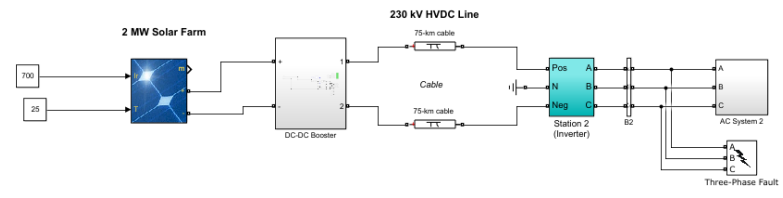

Fig. 10 HVDC model from an offshore farm [27]

Table 8 lists some key points that should be considered when comparing the two as LCC-HVDC is seen as a classical HVDC technology. Some of the reasons why VSC-HVDC is expected to be replacing LCC-HVDC include (a) Improvement in power capabilities, (b) More compact stations, (c) Controllability, (d) Black start capability [28].

Additionally, VSC-HVDC multiterminal connection is a feature that opens more options for integrating multiple offshore farms into the grid. VSC allows a better controllability of the output voltage and stability. Unlike LCC-HVDC, VSCHVDC does not require the input source to be an AC source so it is great for renewable energy integration and remote loads [29]. Figure 9 depicts a typical VSC-HVDC system with its different components, assuming there is an $\mathrm{AC}$ system that feeds the power.

Figure 10 depicts the goal of this study where an HVDC line is to be used for transmitting power from an offshore solar farm. One of the issues encountered is how to integrate the solar farm into the HVDC line. Since the solar farm produces DC power, there is no need for a rectifier. The issue results from this is how to make the farm output voltage compatible with HVDC link. It is possible that the farm voltage output is not as high as the rated voltage of the link.

The solution to the above issue is to use a DC-DC boost converter to raise the farm voltage on the sending end. On the receiving end, we plan to implement VSC to mitigate any power mismatching and noise. A project that has some similarities is the Zhangbei Xiaoertai flexible substation in China which connects a solar plant to a data center [27]. 


\subsection{Power loss and voltage drop of HVDC}

The effectiveness of HVDC transmission can be evaluated using three metrics, namely power loss, voltage drop, and harmonics. In this section we present the findings obtained from reviewing past studies on power loss and voltage drop of HVDC, and comparison with $\mathrm{AC}$ transmission. The typical power loss on transmission lines ranges between $2-4 \%$ for an onshore AC system [30].

When comparing HVDC with HVAC, HVDC typically ignores the inductive voltage drop. A study comparing the losses and voltage drop between these two systems was performed. Various distances ranging between $180 \mathrm{~km}$ to $700 \mathrm{~km}$ are considered. The simulation was performed using ETAP software and the transmission lines are rated at $400 \mathrm{kV}$. The results are presented in Table 9 and Table 10 [25].

Table 9 Power loss and voltage drop HVAC [25]

\begin{tabular}{|r|r|r|}
\hline \multicolumn{3}{|c|}{ AC Power Transmission Results } \\
\hline $\begin{array}{c}\text { Length } \\
(\mathbf{K m})\end{array}$ & $\begin{array}{c}\text { Losses } \\
(\mathbf{M W})\end{array}$ & $\begin{array}{c}\text { Voltage Drop } \\
(\mathbf{\%})\end{array}$ \\
\hline $\mathbf{1 8 0}$ & 2.91 & 2.58 \\
\hline $\mathbf{2 3 0}$ & 3.49 & 3.20 \\
\hline $\mathbf{2 8 0}$ & 4.03 & 3.60 \\
\hline $\mathbf{3 3 0}$ & 4.57 & 3.78 \\
\hline $\mathbf{3 8 0}$ & 5.12 & 3.75 \\
\hline $\mathbf{4 3 0}$ & 5.73 & 3.51 \\
\hline $\mathbf{4 8 0}$ & 6.40 & 3.07 \\
\hline $\mathbf{5 3 0}$ & 7.17 & 2.43 \\
\hline $\mathbf{5 8 0}$ & 8.08 & 1.59 \\
\hline $\mathbf{7 0 0}$ & 11.00 & -1.20 \\
\hline
\end{tabular}

Table 10 Power loss and voltage drop HVDC [25]

\begin{tabular}{|r|r|r|}
\hline \multicolumn{3}{|c|}{ DC Power Transmission Results } \\
\hline $\begin{array}{l}\text { Length } \\
\text { (Km) }\end{array}$ & \multicolumn{1}{l|}{$\begin{array}{l}\text { Losses } \\
\text { (MW) }\end{array}$} & \multicolumn{1}{c|}{$\begin{array}{l}\text { Voltage Drop } \\
\text { (\%) }\end{array}$} \\
\hline $\mathbf{1 8 0}$ & 1.61 & 1.01 \\
\hline $\mathbf{2 3 0}$ & 1.77 & 1.11 \\
\hline $\mathbf{2 8 0}$ & 1.99 & 1.21 \\
\hline $\mathbf{3 3 0}$ & 2.07 & 1.30 \\
\hline $\mathbf{3 8 0}$ & 2.23 & 1.40 \\
\hline $\mathbf{4 3 0}$ & 2.39 & 1.49 \\
\hline $\mathbf{4 8 0}$ & 2.54 & 1.59 \\
\hline $\mathbf{5 3 0}$ & 2.71 & 1.69 \\
\hline $\mathbf{5 8 0}$ & 2.86 & 1.78 \\
\hline $\mathbf{7 0 0}$ & 3.25 & 2.02 \\
\hline
\end{tabular}

The results from Table 9 and Table 10 show that the HVDC system has lower power loss for all distances, as compared with that of the HVAC system. In terms of voltage drop, the HVDC system has lower voltage drop up to the distance of $530 \mathrm{~km}$. For distances longer than $530 \mathrm{~km}$, the HVAC system voltage drop is slightly less than the HVDC system.

\subsection{Implementation of a DC-DC boost converter to raise sending-end farm voltage}

As mentioned in Section 3.1, we use a boost converter to raise the solar farm voltage to an appropriate level to match the rated voltage of the HVDC link that transmits the farm power to the onshore grid.

Figure 11 depicts a typical boost converter. It consists of a DC input voltage, boost inductor, controlled switch, diode, filter capacitor, and a load. With the switch, one can determine the mode for the system operation. This means that it could either store energy in the inductor or release the stored energy through the diode to our RC circuit [29].

The way the converter works is determined by the switch as it will behave differently based on if its open or closed. When the switch is closed, the diode is reverse-biased. This allows the current to flow through the path of the source. As the switch is opened, the current on the inductor will not change instantly and the diode becomes forward biased [26].

The output voltage will depend on the voltage across the inductor which is based on the rate of change of its current which should change linearly. The amount of time the switch is closed affects the output voltage. Equation (14) provides a general understanding of how one can estimate the expected output of a conventional boost converter by determining the duty cycle [31].

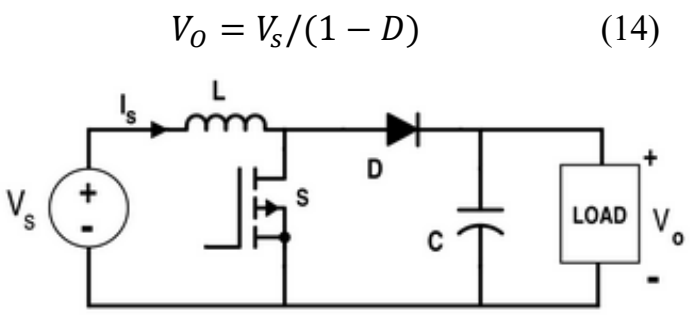

Fig. 11 Conventional DC-DC boost converter [31] 

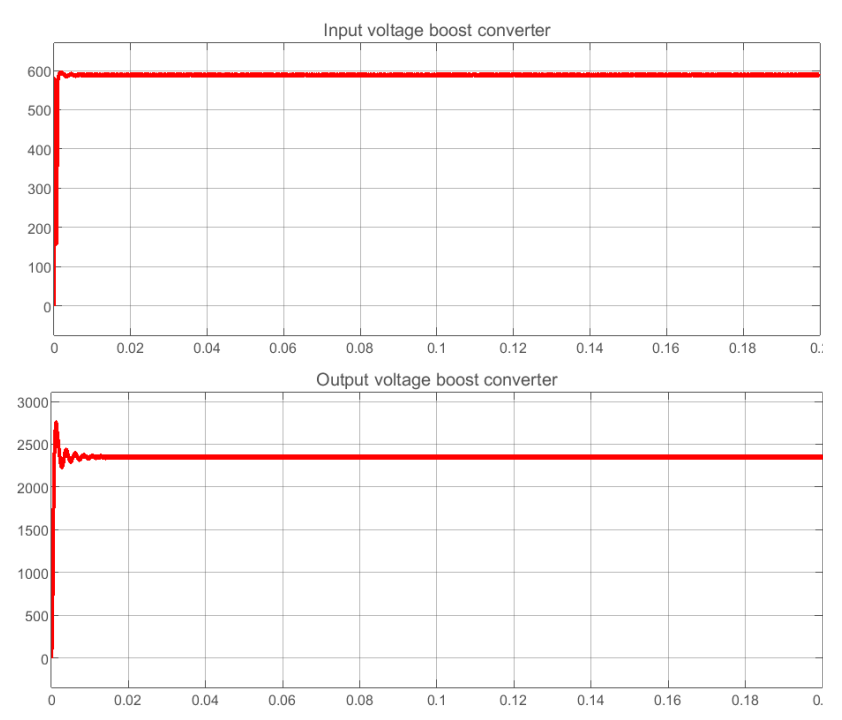

Fig. 12 Input and output voltage from boost converter

As the duty ratio goes up, the denominator of (14) becomes smaller, resulting in a higher output voltage. However, there is a slight trade off. The higher the duty cycle, the more distortion in the output. The next step is to integrate the booster with our bifacial solar panels. Figure 12 depicts the results from applying a boost converter. As seen, it takes approximately $0.012 \mathrm{~s}$ for the voltage to stabilize as the transients subside. The results show the voltage value prior to the boost converter $(600 \mathrm{~V}$, top of Fig. 12) and the voltage value after the booster $(2400 \mathrm{~V}$, bottom of Fig. 12). This way, the sending-end voltage is stepped up by a factor of 4 to match the HVDC link voltage.

\subsection{Mitigating harmonics on the receiving end of HVDC link (onshore grid)}

Harmonics are voltage or current of various frequencies that differ from the grid fundamental frequency $(60 \mathrm{~Hz}$ or $50 \mathrm{~Hz})$. Harmonic problems could lead to catastrophic consequences and huge economic losses. Harmonics can cause waveform distortions, voltage sags, lower efficiency in power generation, reduction in electrical equipment efficiency and durability, creation of harmful resonance situations and so on [32] .

Common producers of harmonics are power electronics equipment such as AC-DC (rectifier), DC to $\mathrm{AC}$ (inverter), $\mathrm{DC}$ to $\mathrm{DC}$ converters, and $\mathrm{AC}$ to $\mathrm{AC}$ converters etc. In our HVDC system, there is an inverter which produces harmonics. As the consequence, the output voltage from the inverter seen on the receiving end (i.e. point of connection with the onshore grid) is severely distorted, as shown in Fig. 13. Figure 14 shows a Simulink FFT analysis that identifies the harmonics being present in the output voltage. Visibly, the output voltage contains lots of harmonics where the Total Harmonic Distortion (THD) is $68.84 \%$.

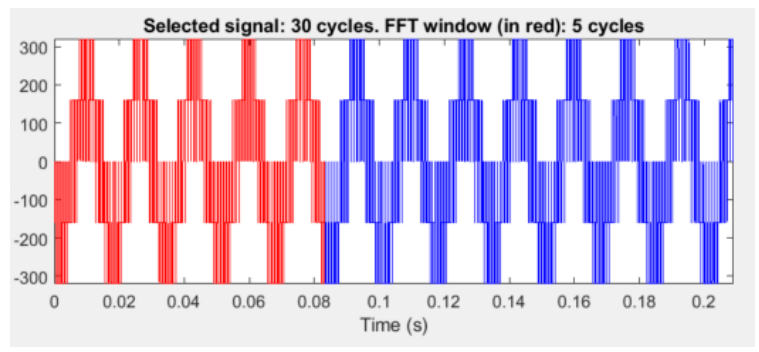

Fig. 13 Voltage output waveform from inverter

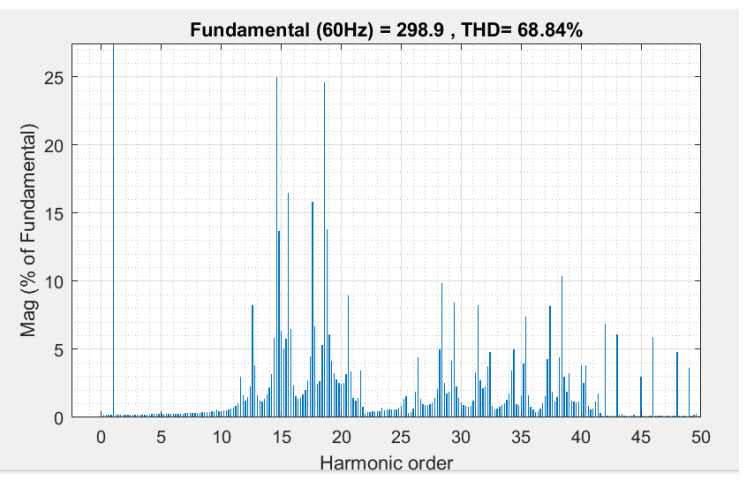

Fig. 14 FFT analysis of inverter output voltage

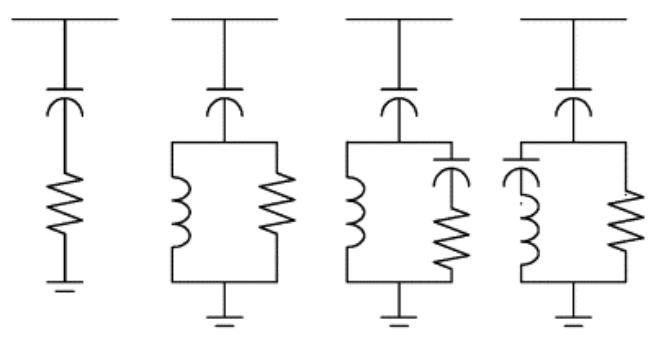

Fig. 15 Common types of filter (From left to right, first order, second order, third order, C-type filter) [33]

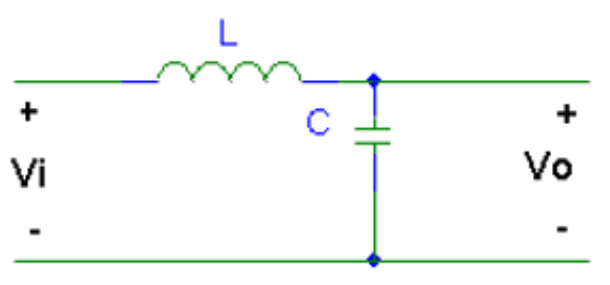

Fig. 16 Lowpass LC filter [34] 
To mitigate the harmonics in the receiving-end voltage, we use passive filters. Figure 15 displays some of the most common filters for harmonic applications.

\section{LC low-pass filter consideration}

An LC second order low-pass filter is considered since it is effective in dealing with higher harmonics. Figure 16 presents the LC filter utilized in our system. The filter is placed between the inverter and the load of the system on the receiving end to mitigate the harmonics. The LC filter cutoff frequency and transfer function equations are shown in (15) and (16). These equations are used to calculate the filter parameters.

$$
\begin{gathered}
f_{C}=\frac{1}{2 \pi \sqrt{L C}} \\
H(\omega)=\frac{1}{1+L C *(j \omega)^{2}}
\end{gathered}
$$

As we try to clear the distortion from our fundamental harmonic, the cutoff frequency is chosen to be $180 \mathrm{~Hz}$. The filter parameters calculated for this cutoff frequency are $\mathrm{L}=35.5 \mathrm{mH}$ and $\mathrm{C}=22 \mathrm{uF}$ where a common size of $22 \mu \mathrm{F}$ is chosen for the capacitor and the inductor size is determined as

$$
\begin{aligned}
L & =\frac{1}{\left(2 \pi f_{c}\right)^{2} C} \\
f_{c}=180 \mathrm{~Hz} ; C & =22 \mu F ; L=35.5 \mathrm{mH}
\end{aligned}
$$

Figure 17 shows the output voltage after applying the low-pass filter with a cutoff frequency of $180 \mathrm{~Hz}$. Compared to the original voltage output in Fig. 13, we notice that the LC filter is very effective in clearing the harmonics. The output voltage THD drops from $68.84 \%$ to $2.99 \%$, as shown by Fig. 18 . Additionally, the magnitude of the voltage output is increased by $12 \%$.

Next, we lower the cutoff frequency to $65 \mathrm{~Hz}$ and recalculate the $\mathrm{LC}$ filter parameters accordingly. The new parameters are $\mathrm{L}=272.5 \mathrm{mH}$ and $\mathrm{C}=22 \mu \mathrm{F}$. The results by applying this new filter are shown in Fig. 19 and Fig. 20.

The results show that the new LC filter performance is slightly better than the one with $180-\mathrm{Hz}$ cutoff frequency. The output voltage waveform (Fig. 19) is cleaner while the THD drop further to $2.93 \%$ (Fig. 20). Based on IEEE standard 519-1992 on harmonic limits, both THD results meet the voltage distortion limit of 5\% for voltage level of $69 \mathrm{kV}$ or less.

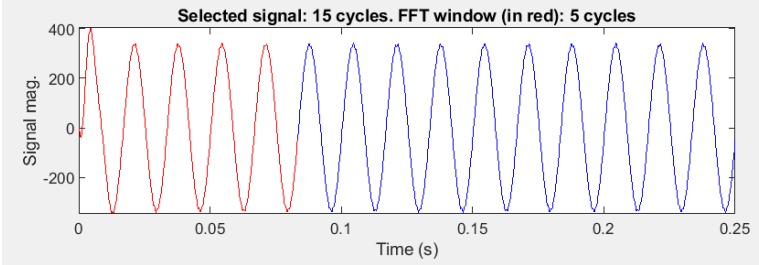

Fig. 17 Output waveform from low-pass LC filter with $180-\mathrm{Hz}$ cutoff frequency

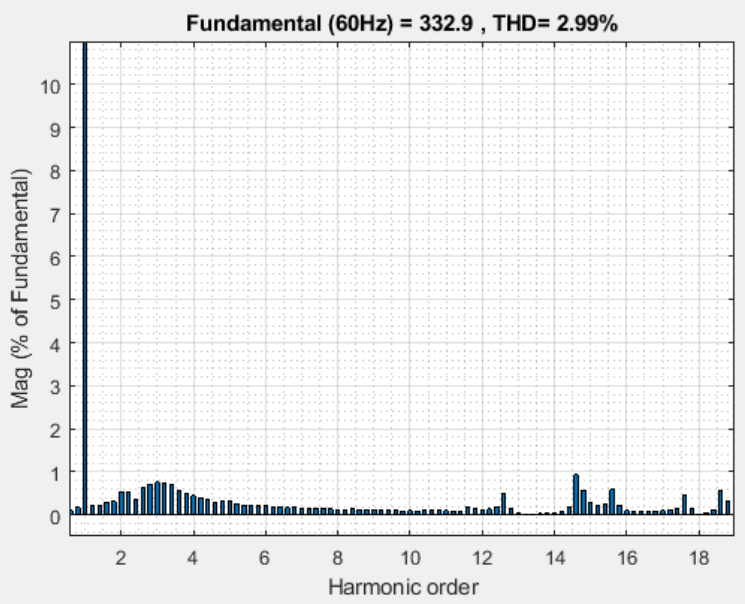

Fig. 18 FFT Analysis after low-pass LC filter with $180-\mathrm{Hz}$ cutoff frequency

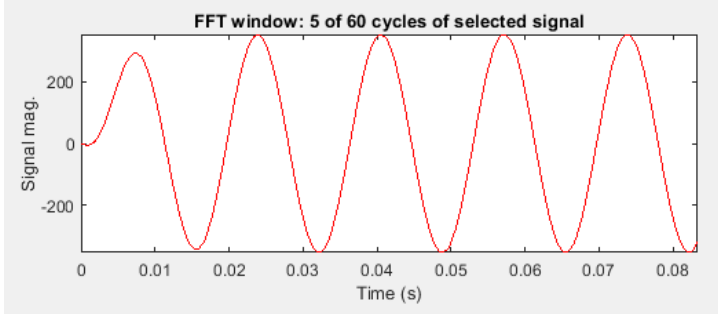

Fig. 19 Output waveform from low-pass LC filter with $65-\mathrm{Hz}$ cutoff frequency

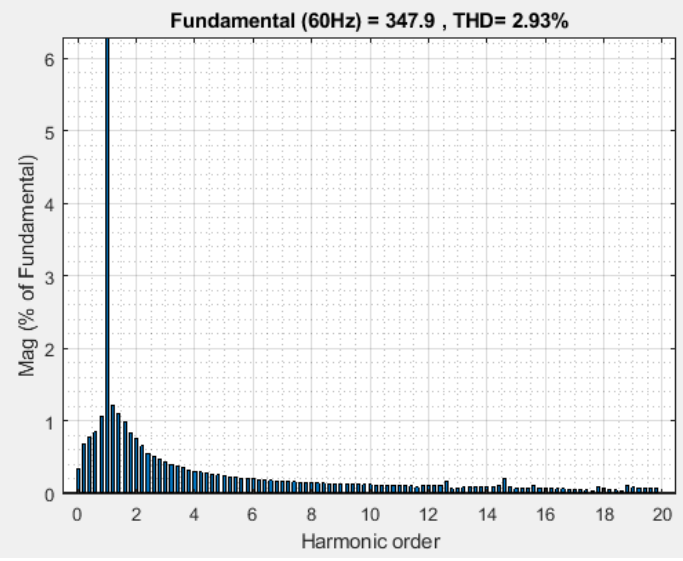

Fig. 20 FFT analysis of output signal from low-pass LC filter with $65-\mathrm{Hz}$ cutoff frequency 


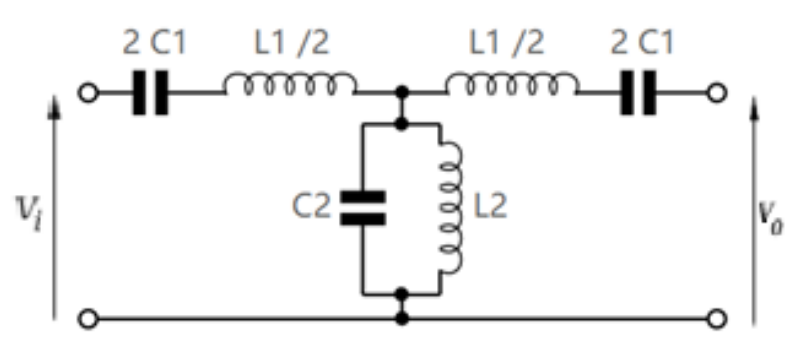

Fig. 21 T-section band-pass filter [35]

\section{T-section band-pass filter and 2-stage filter consideration}

Apart from the LC filter, we have explored a T-section band-pass filter (Fig. 21), and a 2-stage filter where we connect the LC filter in series with the T-section band-pass filter.

The T-section band-pass filter transfer function is shown in (21). Its parameters are determined using (18), (19), (20), and (21) where the center frequency is $60 \mathrm{~Hz}$ and the bandwidth is $10 \mathrm{~Hz}$. This means that the filter pass-band is between $55 \mathrm{~Hz}$ and $65 \mathrm{~Hz}$. Zo is the characteristic impedance which is assumed to be $0.5 \Omega$ while $f_{2}$ is the upper frequency and $f_{1}$ is the lower frequency for our band-pass filter.

$$
\begin{gathered}
f_{1}=55 \mathrm{~Hz} ; f_{2}=65 \mathrm{~Hz} ; Z_{o}=0.5 \Omega \\
L_{1}=\frac{Z_{0}}{\pi\left(f_{2}-f_{1}\right)} H \\
L_{2}=\frac{Z_{0}\left(f_{2}-f_{1}\right)}{4 \pi f_{1} f_{2}} H \\
C_{1}=\frac{f_{2}-f_{1}}{4 \pi f_{1} f_{2} z_{0}} F \\
C_{2}=\frac{1}{\pi Z_{0}\left(f_{2}-f_{1}\right)} F \\
H\left(\omega_{1}, \omega_{2}\right)=\frac{Z_{c 2} \| Z_{L 2}}{2\left(Z_{c 2} \| Z_{L 2}\right)+Z_{c 1}+Z_{L 1}}
\end{gathered}
$$

The obtained parameters for the T-section band-pass filter are: $\mathrm{L}_{1}=15.9 \mathrm{mH}, \mathrm{L}_{2}=11.1 \mathrm{mH}, \mathrm{C}_{1}=44.5 \mathrm{uF}$, $\mathrm{C}_{2}=63.7 \mathrm{mF}$.

The results of the bandpass filter and the 2-stage filter are summarized in Table 11, along with the results of the LC low-pass filters.

Table 11 shows that the THD of the band-pass filter is $49.52 \%$ which is lower than the original THD of $68.84 \%$. The 2-stage filter brings the THD down to $13.68 \%$. However, these outcomes are worse than those of the low-pass filters. It is also observed that the band-pass filter and the 2-filter lead to attenuation of the output. These are helpful experiences when considering these filters for dealing with similar signals.
Table 11 Summary of results for all filters

\begin{tabular}{|c|c|c|}
\hline $\begin{array}{c}\text { Considered } \\
\text { Filters }\end{array}$ & Parameters & Results \\
\hline $\begin{array}{c}\text { Low-pass filter } \\
\text { (LPF) }\end{array}$ & $\begin{array}{c}\text { Cutoff Frequency } \\
180 \mathrm{~Hz}\end{array}$ & THD $2.99 \%$ \\
\hline LPF & $\begin{array}{c}\text { Cutoff Frequency } \\
65 \mathrm{~Hz}\end{array}$ & THD $2.93 \%$ \\
\hline $\begin{array}{c}\text { Band-pass } \\
\text { filter (BPF) }\end{array}$ & $\begin{array}{c}\text { Center Frequency } \\
60 \mathrm{~Hz} \\
\text { Bandwidth } 10 \mathrm{~Hz}\end{array}$ & $\begin{array}{c}\text { THD } 49.52 \% \\
\text { Signal attenuated }\end{array}$ \\
\hline $\begin{array}{c}\text { (LPF) Cutoff } \\
\text { Two-staged } \\
\text { Filter } \\
\text { (LPF-BPF) }\end{array}$ & $\begin{array}{c}\text { Frequency } 180 \mathrm{~Hz} \\
\text { (BPF) Center } \\
\text { Frequency } 60 \mathrm{~Hz} \\
\text { Bandwidth } 10 \mathrm{~Hz}\end{array}$ & $\begin{array}{c}\text { THD 13.68\% } \\
\text { Signal attenuated }\end{array}$ \\
\hline
\end{tabular}

\section{Conclusion}

In this study, two methods to enhance the power production efficiency of offshore solar farms are investigated. The goals are: (i) To improve PV system efficiency through utilization of bifacial panels. The bifacial panels are expected to be used in offshore solar farms and (ii) To improve solar power transmission effectiveness using HVDC links.

The first approach focuses on modeling bifacial panels, determining their efficiency and comparing their efficiency with that of monofacial panels. The second approach explores power transmission effectiveness of HVDC lines in terms of power loss, voltage drop, and harmonic situation. Filters has been designed to mitigate harmonics coming from considered HVDC link inverter. The results have led to the following conclusion:

1) The bifacial panel is considerably more efficient compared to the monofacial panel. For a wide range of irradiance $\left(100-1000 \mathrm{~W} / \mathrm{m}^{2}\right)$, the bifacial panel produces more power than the monofacial panel by $8.5 \%$ to $24.8 \%$. The bifacial panel outputs over $24 \%$ more power for lower irradiance levels, namely $100-600 \mathrm{~W} / \mathrm{m}^{2}$.

2) The HVDC lines are promising solution for transmitting power from offshore solar farms to the onshore grid. The newer Voltage Source Converter (VSC) HVDC has high potential for future deployment thanks to its advantages.

3) Harmonics from HVDC link inverter can be very severe. However, the harmonics may be effectively mitigated using LV low-pass filters. The implemented low-pass filters have remarkably reduced the voltage output harmonics from $68.84 \%$ to $2.93 \%$, resulting in a 
clean sinusoidal waveform acceptable for the onshore grid.

In terms of broader impact, the results from the study can be helpful for developing offshore solar farms using bifacial PV panels and HVDC. The offshore solar farms will help solve land-occupation problems by providing green and clean energy while preserving land for growing food and inhabitation.

\section{Acknowledgement}

The authors would like to thank the Master project committee members, Dr. Sean Monemi and Dr. Zekeriya Aliyazicioglu for their time and feedback. The author Bell David Du Hong would like to thank his project advisor, Dr. Ha Thu Le, who has helped him throughout the project.

\section{References}

[1] "Renewables 2019: Global Status Report," 2019.

[2] C. Carl, "Calculating solar photovoltaic potential on residential rooftops in Kailua Kona, Hawaii," Masters of Science, Geographic Information Science and Technology, University of Southern California, 2014.

[3] H. Cao, J. Gonzales, N. Dimetry, J. Cate, R. Huynh, and H. T. Le, "A solar-based Versatile Charging Station for Consumer AC-DC Portable Devices," International Journal of Power Systems, vol. 4, pp. 115-131, 2019.

[4] B. Postovoit, D. Susoeff, D. Daghbas, J. Holt, and H. T. Le, "A Solar-Based Stand-Alone Family House for Energy Independence and Efficiency," in IEEE Conference on Technologies for Sustainability (SusTech), 2020: IEEE, pp. 1-6.

[5] S. C. Ganilha, "Potential of bifacial PV installation and its integration with storage solutions," Geographic Engineering, University of Lisbon, 2017.

[6] I. Sowa, "Impedance-based analysis of harmonic resonances in HVDC connected offshore wind power plants," Electric Power Systems Research, vol. 166, pp. 61-72, 2019 2019.
[7] S. F. Hui, "Offshore floating solar farm development programme," presented at the The 11th IET International Conference on Advances in Power System Control, Operation and Management, Hong Kong, China, 2018.

[8] A. Hasan, "A new performance assessment methodology of bifacial photovoltaic solar panels for offshore applications," Energy Conversion and Management, vol. 220, 2020.

[9] M. Sankrithi, "Preliminary design \& analysis of low-cost concentrating offshore solar energy innovations," presented at the SOLAR 2018 47th National Solar Conference of the American Solar Energy Society, 2018, 2018.

[10] M. R. Khan, "Vertical bifacial solar farms: Physics, design, and global optimization," Applied Energy, vol. 206, pp. 240-248, 2017, doi: 10.1016/j.apenergy.2017.08.042.

[11] S. A. Pelaez, "Bifacial Solar Modules System Design, Modeling, and Performance," Department of Electrical and Computer Engineering, University of Arizona, 2019.

[12] A. Bidadfar, "Coordinated control of HVDC and HVAC power transmission systems integrating a large offshore wind farm," Energies, vol. 12, no. 18, doi: 10.3390/en12183435.

[13] "Offshore Wind Power." https://en.wikipedia.org/wiki/Offshore_wind_ power (accessed Oct. 18, 2020).

[14] L. Wang, "Stability Analysis of a Microgrid System with a Hybrid Offshore Wind and Ocean Energy Farm Fed to a Power Grid Through an HVDC Link," IEEE Transactions on Industry Applications, vol. 54, 3, p. 8, 2018, doi: 10.1109/TIA.2017.2787126.

[15] E. Chu. "A Brief History of Solar Panels." https://www.smithsonianmag.com/sponsored/b rief-history-solar-panels-180972006/ (accessed Nov-14, 2020).

[16] S. McFadyen. "Photovoltaic Electrical Calculation."

https://myelectrical.com/notes/entryid/225/pho tovoltaic-pv-electrical-calculations (accessed Nov-16, 2020).

[17] C. Duran, "Bifacial Solar Cells: High Efficiency Design, Characterization, Modules and Applications," Doctor of Science, University of Konstanz, 2012. 
[18] C. Honsberg. "Equations for Photovoltaics." https://www.pveducation.org/pvcdrom/append ices/equations/equations-for-photovoltaics (accessed Oct-21, 2020).

[19] N. Ishikawa, "World First Large Scale 1.25MW Bifacial PV Power Plant on Snowy Area in Japan," Bifacial PV Workshop, vol. 3, 2016 2016.

[20] S. Chunduri, "Bifacial Solar Module Technology," TaiyanNews, 2017.

[21] M. Chiodetti, "PVbifacial Yield simulation with variable albedo model," 2016.

[22] "Calculating the Additional Energy Yield of Bifacial Solar Module," SolarWorld, 2015.

[23] "Albedo." https://climate.ncsu.edu/edu/Albedo (accessed Nov 18, 2020).

[24] "Ideal Direction for Solar Panels in California." https://longtermsolar.com/ideal-direction-forsolar-panels-incalifornia/\#: :text=The $\% 20$ angle $\% 20$ is $\% 20$ ba sed\%20on,work\%20best $\% 20$ in\%20Los\%20A ngeles. (accessed Nov-29, 2020).

[25] S. McFadyen. "HDVC Transmission." https://circuitglobe.com/hvdc-high-voltagedirect-current.html (accessed Feb 16, 2021).

[26] D. Jovcic, High Voltage Direct Current Transmision: Converters, Systems and DC Grids, Second ed. John Wiley \& Sons Ltd, 2019.

[27] J. Zhou, "Overview on VSC-HVDC Systems Based on PV," presented at the Energy Conversion and Management, 2020.

[28] O. Oni, "A review of LCC-HVDC and VSCHVDC technologies and applications," presented at the 2016 IEEE 16th International Conference on Environment and Electrical Engineering (EEEIC), Florence, Italy, 2016.
[29] J. V. Burkleo. "HVDC: The Key to Revolutionizing the Renewable Energy Grid." (accessed Feb 17, 2021).

[30] J. Schonek. "How big are Power line losses?" https://blog.se.com/energy-managementenergy-efficiency/2013/03/25/how-big-arepower-line-

losses/\#: :text=The\%20transmission\%20over $\% 20$ long $\% 20$ distances,as $\% 20$ heat $\% 20 \mathrm{in} \% 20 \mathrm{t}$ he $\% 20$ conductors.\&text $=$ The $\% 20$ overall $\% 201$ osses $\% 20$ between $\% 20$ the,range $\% 20$ between $\%$ 208\%20and\%2015\%25 (accessed.

[31] D. Hart, Power Electronics, First ed. McGrill Hill, 2011.

[32] S. Santoso, Fundamentals of Electric Power Quality. CreateSpace Independent Publishing Platform, 2012.

[33] "Passive Filter Design." PSCAD. https://www.pscad.com/webhelp/Master_Libra ry_Models/Passive/Filters/Passive_Filter_Desi gn.htm (accessed March, 2021).

[34] M. Sadiku, Fundamentals of Electric Circuits, Fourth ed. McGrill Hill, 2009.

[35] "Constant-K LC Band Pass Filter Circuit Design \& Calculations." https://www.electronicsnotes.com/articles/radio/rf-filters/constant-ksimple-bandpass-lc-rf-filter-designcalculations.php (accessed April, 2021).

\section{Creative Commons Attribution License 4.0 (Attribution 4.0 International, CC BY 4.0)}

This article is published under the terms of the Creative Commons Attribution License 4.0 https://creativecommons.org/licenses/by/4.0/deed.en_US 